\title{
Crosslink bio-adhesives for bronchoscopic lung volume reduction: current status and future direction
}

\author{
Mugdha M. Joglekar ${ }^{1,2}$, Dirk-Jan Slebos $\mathbb{1}^{3}$, Jeroen Leijten ${ }^{4}$, Janette K. Burgess $\mathbb{( i D}^{1,2}$ and \\ Simon D. Pouwels $\mathbb{1}^{1,2,3}$
}

${ }^{1}$ University of Groningen, University Medical Center Groningen, Dept of Pathology and Medical Biology, Groningen, The Netherlands. ${ }^{2}$ University of Groningen, University Medical Center Groningen, Groningen Research Institute for Asthma and COPD, Groningen, The Netherlands. ${ }^{3}$ University of Groningen, University Medical Center Groningen, Dept of Pulmonary Diseases, Groningen, The Netherlands. ${ }^{4}$ Dept of BioEngineering, TechMed Centre, University of Twente, Enschede, The Netherlands.

Corresponding author: Simon D. Pouwels (s.d.pouwels@umcg.nl)

Shareable abstract (@ERSpublications)

We present an overview of current literature on tissue sealants and haemostats used for lung repair and regeneration. Furthermore, an in-depth description of different lung tissue adhesives and the characteristics of an ideal lung adhesive is provided. https://bit.ly/2YmPhre

Cite this article as: Joglekar MM, Slebos D-J, Leijten J, et al. Crosslink bio-adhesives for bronchoscopic lung volume reduction: current status and future direction. Eur Respir Rev 2021; 30: 210142 [DOI: 10.1183/16000617.0142-2021].

\section{Abstract}

Copyright @The authors 2021 Several bronchoscopic lung volume reduction (BLVR) treatments have been developed to reduce hyperinflation in emphysema patients. Lung bio-adhesives are among the most promising new BLVR treatment options, as they potentially provide a permanent solution for emphysematous patients after only a single application. To date, bio-adhesives have mainly been used as haemostats and tissue sealants, while their application in permanently contracting and sealing hyperinflated lung tissue has recently been identified as a novel and enticing opportunity. However, a major drawback of the current adhesive technology is the induction of severe inflammatory responses and adverse events upon administration. In our review, we distinguish between and discuss various natural, semi-synthetic and synthetic tissue haemostats and sealants that have been used for pulmonary applications such as sealing air/fluid leaks. Furthermore, we present an overview of the different materials including AeriSeal and autologous blood that have been used to achieve lung volume reduction and discuss their respective advantages and drawbacks. In conclusion, we describe the key biological (therapeutic benefit and biocompatibility) and biomechanical (degradability, adhesive strength, stiffness, viscoelasticity, tunability and self-healing capacity) characteristics that are essential for an ideal lung bio-adhesive material with the potential to overcome the concerns related to current adhesives.

Introduction

COPD is a progressive and chronic inflammatory lung disease that affects more than 300 million people globally [1]. Pulmonary emphysema and chronic bronchitis are recognised as the two major phenotypes of COPD [1]. Emphysema is characterised by the permanent enlargement of alveoli distal to terminal bronchioles accompanied by tissue destruction [2]. This pathological process results in inefficient gas exchange and loss of elastic recoil of the lung tissue [2]. As a result, expiratory air gets trapped within the damaged tissue and over time, leading to hyperinflation of the affected tissue. Emphysematous patients hence suffer from shortness of breath, cough and decreased ability to perform physical activities. The development of emphysema is primarily attributed to prolonged exposure to noxious gases from sources such as smoking, exhaust fumes and air pollution [1,3]. COPD has remained an incurable condition, while limited treatment options exist to slow its progression and increase the quality of life [2, 4].

One intervention to treat COPD is lung volume reduction surgery (LVRS). In LVRS, the most emphysematous part of the lung is surgically resected, thereby reducing the lung hyperinflation and allowing natural resizing of the remaining healthier tissue. In turn, this improves respiratory muscle and 
diaphragmatic function. This treatment has imparted survival benefit to a selected group of patients with advanced heterogeneous emphysema and low exercise capacity. However, it is associated with high rates of morbidity, making it a rather exclusive therapy for a small subpopulation of COPD patients [5]. These factors incentivised the development of minimally invasive lung volume reduction methods commonly referred to as bronchoscopic lung volume reduction (BLVR) treatments [4, 6]. In this review, we briefly discuss the various strategies for BLVR that have been developed so far. One such technique gaining ground in the field of BLVR is the use of lung bio-adhesive materials to permanently contract and block emphysematous tissue. Until recently, the use of most lung bio-adhesives has been limited to haemostatic or sealant applications. Hence, we present a consolidated overview of the various tissue sealants and haemostats used to seal air/liquid leakages and stimulate lung repair and regeneration. Additionally, we discuss in detail the different lung tissue adhesives that have been used to achieve volume reduction in COPD patients. In closing, we describe the characteristics of an ideal lung bio-adhesive for BLVR, capable of overcoming issues related to current adhesive technologies.

Bronchoscopic lung volume reduction

BLVR treatments currently include the implantation of medical devices such as one-way endobronchial valves (EBV) and endobronchial coils, airway bypass stents, thermal vapour ablation and the local application of polymeric sealants or bio-adhesives [4, 6]. These methods can be classified based on their mechanism of action, degree of reversibility and safety (table 1). Notably, precise patient selection is imperative for achieving maximal beneficial outcomes from these techniques. The type (homogeneous versus heterogeneous) and severity of the emphysematous tissue destruction as well as the level of fissure integrity drive the choice of the preferred BLVR strategy to be used [32]. For example, presence of collateral ventilation is an exclusion criterion for EBV treatment. A recent retrospective study by WELLING et al. [33] further demonstrated the exclusivity of BLVR treatment. Out of all patients referred to BLVR, only $20 \%$ fulfilled the criteria for treatment, but these selected individuals upon treatment lived significantly longer than ineligible patients [33]. Additionally, these therapeutic options have conferred benefits such as improved lung function and enhanced physical exercise capacity among COPD patients to varying extents, all leading to improved quality of life [7, 8, 15, 23, 34, 35]. Therefore, while BLVR therapies are exclusive, they are highly effective and remain a top choice of treatment for patients not eligible for LVRS. The various BLVR practices as well as the status and outcome of the applicable clinical studies have been discussed in detail elsewhere [5, 36].

\section{Lung haemostats, sealants and bio-adhesives}

During surgical interventions for lung cancer and emphysema, part of the lung tissue is resected [37]. This type of surgical intervention risks post-operative blood and air leakage into the pleural cavity [37]. Sutures, staples and wires are typically used to maintain tissue integrity, although they have certain limitations such as invasiveness, risk of further tissue damage and infection, time requirements during placement, and inaccessibility of the defect site [38]. The application of surgical adhesive biomaterials is a popular option to use directly on the air or liquid leaks or to reinforce the standard techniques [39] (table 2). These materials can behave as haemostats, sealants and tissue adhesives (or a combination of the three) [45, 53], as illustrated in figure 1. These sealants are desirable given their application is quick and easy [38, 53].

Sealants can be classified as natural, synthetic or semi-synthetic [38, 53]. Sealants composed of fibrin, albumin, collagen and chitosan are examples of natural sealants such as Tisseel (Baxter International, IL, USA), Tachosil (Takeda Pharmaceutical, Tokyo, Japan), BioGlue (CryoLife, GA, USA) and Eviseal (Ethicon, NJ, USA). Components of natural sealants and adhesives derived from human plasma and animal serum, such as fibrin- and albumin-based sealants, carry the inherent risk of disease transmission and allergic reactions [38, 53]. Naturally derived materials typically associate with lower mechanical properties such as the rigidity of BioGlue and relatively fast degradation of Progel [44, 54]. Cyanoacrylates, polyvinyl alcohol, polyethylene oxide and polyethylene glycol are well known examples of popular polymers used as synthetic sealants, which includes Histoacryl (B. Braun, Melsungen, Germany), FocalSeal (Genzyme Corp, MA, USA; currently discontinued), Coseal (Cohesion Technologies, CA, USA) and AeriSeal (PulmonX Corp, CA, USA). Synthetic polymers are often associated with in vivo toxicity. For example, during polymerisation cyanoacrylates can cause thermal damage and scarring and their by-products formed during degradation are cytotoxic in nature, which can lead to necrosis of tissue $[45,46]$. The high stiffness of these synthetic polymers also restricts physiological movements of organs such as lungs and heart [45]. Moreover, these polymers prefer adherence to dry surfaces, hence are unable to function in wet environments [45]. This has limited their application to topical use. Conversely, adhesive materials have also been developed for BLVR. The currently available BLVR bio-adhesive, AeriSeal, induces inflammatory responses upon administration that stimulate the formation of fibrotic tissue, which consequently contracts and reduces the overall volume of the lungs [55]. 
TABLE 1 Bronchoscopic lung volume reduction techniques

\begin{tabular}{|c|c|c|c|c|c|}
\hline \multirow{3}{*}{$\begin{array}{l}\text { Mechanism of } \\
\text { action }\end{array}$} & \multirow{3}{*}{$\begin{array}{l}\text { Endobronchial valves } \\
\\
\text { Implantation of } \\
\text { unidirectional valves } \\
\text { block inhaled air from } \\
\text { entering targeted } \\
\text { airways, while allowing } \\
\text { trapped air and } \\
\text { secretions from distal } \\
\text { airways and } \\
\text { parenchymal tissue to } \\
\text { escape during } \\
\text { exhalation }\end{array}$} & \multirow{3}{*}{$\begin{array}{l}\text { Airway bypass stents } \\
\text { Anatomical fenestrations } \\
\text { are created between } \\
\text { bronchial walls and } \\
\text { hyperinflated parenchymal } \\
\text { tissue followed by insertion } \\
\text { of a small drug-eluting } \\
\text { paclitaxel-coated stent; } \\
\text { these act as transbronchial } \\
\text { passageways that allow } \\
\text { decompression of the } \\
\text { damaged tissue and } \\
\text { increase gas flow from the } \\
\text { hyperinflated region into } \\
\text { the main airway during } \\
\text { exhalation }\end{array}$} & \multicolumn{3}{|c|}{ Affecting lung parenchyma } \\
\hline & & & Coils & $\begin{array}{l}\text { Thermal vapour } \\
\text { ablation }\end{array}$ & Sealants \\
\hline & & & $\begin{array}{l}\text { Implantation of coils } \\
\text { in targeted airways } \\
\text { results in } \\
\text { compression and } \\
\text { retraction of the } \\
\text { hyperinflated lung } \\
\text { parenchyma, } \\
\text { restoring elastic } \\
\text { recoil of the } \\
\text { healthier tissue }\end{array}$ & $\begin{array}{l}\text { Heated water } \\
\text { vapour is used to } \\
\text { thermally damage } \\
\text { lung parenchymal } \\
\text { tissue and induce } \\
\text { fibrotic responses; } \\
\text { this leads to the } \\
\text { formation of scar } \\
\text { tissue that } \\
\text { stimulates } \\
\text { contraction of the } \\
\text { lung, reducing the } \\
\text { overall volume }\end{array}$ & $\begin{array}{l}\text { Lung adhesives are } \\
\text { locally delivered that } \\
\text { polymerise in situ } \\
\text { and induce } \\
\text { inflammatory and } \\
\text { fibrotic responses; } \\
\text { this leads to the } \\
\text { formation of scar } \\
\text { tissue and reduction } \\
\text { in lung volume }\end{array}$ \\
\hline $\begin{array}{l}\text { Reported } \\
\text { complications } \\
\text { and adverse } \\
\text { events }\end{array}$ & $\begin{array}{c}\text { Valve migration/ } \\
\text { misplacement, } \\
\text { granulation tissue } \\
\text { formation, lack of } \\
\text { benefit, pneumonia, } \\
\text { pneumothorax, COPD } \\
\text { exacerbations, severe } \\
\text { haemoptysis, pulmonary } \\
\text { infections and death }\end{array}$ & $\begin{array}{c}\text { Granulation tissue } \\
\text { formation, COPD } \\
\text { exacerbations, respiratory } \\
\text { infections, pneumothorax } \\
\text { and haemoptysis }\end{array}$ & $\begin{array}{c}\text { Pneumothorax, } \\
\text { pneumonia, COPD } \\
\text { exacerbations, chest } \\
\text { pain and } \\
\text { haemoptysis }\end{array}$ & $\begin{array}{l}\text { Pneumonia, COPD } \\
\text { exacerbations, } \\
\text { respiratory tract } \\
\text { infection, } \\
\text { haemoptysis and } \\
\text { death }\end{array}$ & $\begin{array}{l}\text { Breathlessness, } \\
\text { thrombosis, fever } \\
\text { pulmonary embolus, } \\
\text { leukocytosis, } \\
\text { increased C-reactive } \\
\text { protein, COPD } \\
\text { exacerbations, } \\
\text { pneumonia, } \\
\text { haemoptysis, } \\
\text { respiratory infections } \\
\text { and death }\end{array}$ \\
\hline Reversibility & Reversible & Reversible & Partially reversible & Nonreversible & Nonreversible \\
\hline Examples & $\begin{array}{l}\text { Zephyr valve (PulmonX } \\
\text { Corp, CA, USA), The } \\
\text { Spiration IBV Valve } \\
\text { System (Olympus, WA, } \\
\text { USA) }\end{array}$ & $\begin{array}{c}\text { Exhale Emphysema } \\
\text { Treatment System (Broncus } \\
\text { Technologies, CA, USA) }\end{array}$ & $\begin{array}{c}\text { RePneu }^{\#} \text { (PneumRx, } \\
\text { CA, USA), } \\
\text { Lung Tensioning } \\
\text { Device (FreeFlow } \\
\text { Medical, CA, USA) }\end{array}$ & $\begin{array}{c}\text { Uptake Medical } \\
\text { InterVapor (Broncus } \\
\text { Technologies, CA, } \\
\text { USA) }\end{array}$ & $\begin{array}{l}\text { AeriSeal (PulmonX } \\
\text { Corp, CA, USA) }\end{array}$ \\
\hline $\begin{array}{l}\text { Examples of } \\
\text { randomised } \\
\text { controlled } \\
\text { clinical trials }\end{array}$ & $\begin{array}{c}\text { STELVIO, IMPACT, } \\
\text { LIBERATE, TRANSFORM }\end{array}$ & EASE $^{\#}$ & $\begin{array}{c}\text { RENEW, RESET, } \\
\text { EFFORT }\end{array}$ & STEP-UP & ASPIRE \\
\hline References & {$[7-14]$} & {$[15,16]$} & [17-22] & [23-26] & {$[27-31]$} \\
\hline
\end{tabular}

Adhesion under wet conditions, such as the lung tissue, is particularly challenging. However, a subclass of tissue adhesives that bind specifically to mucous membranes, called mucoadhesives, has been extensively studied to address this concern. Mucoadhesives have prominently been implemented as drug delivery systems for respiratory diseases and often have been developed using polymers functionalised with phenolic compounds such as catechol groups to enhance their adhesive properties [56-58]. Catechol is the key component of the amino acid 3,4-dihydroxy-L-phenylalanine (DOPA), a major protein secreted by mussels to latch onto surfaces underwater $[52,59]$. The adhesive properties of mussels have been most studied for myriad biomedical applications, for example wound closure, extrahepatic islet transplantation and fetal membrane repair [60-62]. To the best of our knowledge, besides autologous blood, the application of biomimetic tissue adhesives as bronchoscopic intervention for emphysema has not been reported. These mussel-inspired adhesive biomaterials are biocompatible, have strong adhesive properties especially under wet conditions, polymerise rapidly and can be altered to obtain desirable biomechanical properties [45, 52]. However, high production cost and auto-oxidation at higher $\mathrm{pH}$ of these substances currently challenges their clinical implementation [52, 59].

Lungs are active immunological sites that present a wet environment due to the presence of surfactant mucus [63]. Furthermore, lungs are soft and highly elastic organs [64]. The constant movement of the 
TABLE 2 Sealants and adhesives used for clinical pulmonary applications

Composition

Examples

Mechanism of action

Characteristics

References

\begin{tabular}{|c|c|c|c|c|c|}
\hline \multicolumn{6}{|l|}{$\begin{array}{l}\text { Lung volume } \\
\text { reduction }\end{array}$} \\
\hline PVA & $\begin{array}{l}\text { Aminated PVA } \\
\text { Glutaraldehyde }\end{array}$ & $\begin{array}{l}\text { AeriSeal (PulmonX } \\
\text { Corp, CA, USA) }\end{array}$ & $\begin{array}{l}\text { Local delivery and in situ } \\
\text { polymerisation induces } \\
\text { inflammatory responses, } \\
\text { fibrosis and scar tissue } \\
\text { formation, promoting } \\
\text { atelectasis }\end{array}$ & $\begin{array}{l}\text { Degradable, and invokes } \\
\text { inflammatory responses }\end{array}$ & {$[27,29,31]$} \\
\hline $\begin{array}{l}\text { Autologous } \\
\text { blood }\end{array}$ & $\begin{array}{l}\text { Autologous blood } \\
\text { Fibrinogen } \\
\text { Thrombin }\end{array}$ & & $\begin{array}{l}\text { Blood clot formation is } \\
\text { instigated at site which } \\
\text { supports plugging of } \\
\text { emphysematous tissue }\end{array}$ & $\begin{array}{l}\text { Low cost, higher risk of } \\
\text { infection and usually used } \\
\text { as a last-resort treatment }\end{array}$ & [40-43] \\
\hline \multicolumn{6}{|l|}{$\begin{array}{l}\text { Sealing air/fluid } \\
\text { leaks }\end{array}$} \\
\hline Fibrin & $\begin{array}{l}\text { Fibrinogen } \\
\text { Thrombin } \\
\text { Factor XIII }\end{array}$ & $\begin{array}{c}\text { Vivostat Fibrin } \\
\text { Sealant (Vivostat A/S } \\
\text { Alleroed, Denmark); } \\
\text { Tisseel (Baxter } \\
\text { International, IL, } \\
\text { USA) }\end{array}$ & $\begin{array}{l}\text { Upon administration, } \\
\text { fibrinogen is converted to } \\
\text { fibrin in the presence of } \\
\text { thrombin; fibrin forms } \\
\text { clots which covalently } \\
\text { bond with tissue with the } \\
\text { help of factor XIII; this } \\
\text { process is accelerated by } \\
\text { addition of calcium ions }\end{array}$ & $\begin{array}{l}\text { Neo-angiogenesis, normal } \\
\text { wound healing, degradable, } \\
\text { risk of disease transmission } \\
\text { or allergic reactions as a } \\
\text { derivative of human/animal } \\
\text { plasma, unclear efficiency in } \\
\text { wet environment and poor } \\
\text { mechanical properties }\end{array}$ & {$[38,44]$} \\
\hline Cyanoacrylates & $\begin{array}{l}\text { N-butyl cyanoacrylate } \\
\text { Methacryloxysulpholane } \\
\text { 2-octyl cyanoacrylate } \\
\text { Butyl lactoyl } \\
\text { cyanoacrylate }\end{array}$ & $\begin{array}{c}\text { Glubran2 (GEM, } \\
\text { Tuscany, Italy); } \\
\text { Omnex (Ethicon, NJ, } \\
\text { USA) }\end{array}$ & $\begin{array}{c}\text { Cyanoacrylates upon } \\
\text { application polymerise in } \\
\text { the presence of weak bases } \\
\text { found in bodily fluids and } \\
\text { blood including water and } \\
\text { amines }\end{array}$ & $\begin{array}{l}\text { Wet adhesion, rapid curing, } \\
\text { low cost, inflammatory } \\
\text { reactions induced, } \\
\text { degradable, exothermic } \\
\text { polymerisation and toxic } \\
\text { byproducts }\end{array}$ & [45-47] \\
\hline Albumin & $\begin{array}{l}\text { Albumin } \\
\text { Glutaraldehyde } \\
\text { PEG }\end{array}$ & $\begin{array}{l}\text { BioGlue (CryoLife, } \\
\text { GA, USA); Progel } \\
\text { (BD, NJ, USA) }\end{array}$ & $\begin{array}{l}\text { Lysine molecules in } \\
\text { albumin, extracellular } \\
\text { matrix, and cell surfaces } \\
\text { crosslink upon } \\
\text { glutaraldehyde exposure }\end{array}$ & $\begin{array}{l}\text { Degradable, instigate } \\
\text { inflammatory response, } \\
\text { rigid, cytotoxic }\end{array}$ & {$[44,48-51]$} \\
\hline PEG & $\begin{array}{c}\text { PEG } \\
\text { Polylactic acid } \\
\text { Polytrimethylene } \\
\text { carbonate }\end{array}$ & $\begin{array}{c}\text { FocalSeal (Genzyme } \\
\text { Corp, MA, USA); } \\
\text { Coseal (Cohesion } \\
\text { Technologies, CA, } \\
\text { USA) }\end{array}$ & $\begin{array}{l}\text { PEG is modified with } \\
\text { degradable functionalities } \\
\text { or crosslinked with } \\
\text { degradable polymers to } \\
\text { confer adhesiveness and } \\
\text { tissue bonding }\end{array}$ & $\begin{array}{l}\text { Controlled degradation, } \\
\text { flexibility, high adhesion } \\
\text { strength and } \\
\text { biocompatibility, high } \\
\text { swelling ratio and low } \\
\text { cohesive strength and } \\
\text { brittleness }\end{array}$ & {$[38,52]$} \\
\hline Collagen & Collagen & $\begin{array}{l}\text { Peri-Strips (Synovis } \\
\text { Life Technologies, } \\
\text { MN, USA) }\end{array}$ & $\begin{array}{l}\text { Presents an adhesive } \\
\text { matrix to provide } \\
\text { additional clotting factors } \\
\text { and to control bleeding; } \\
\text { the matrix covalently binds } \\
\text { to the tissue }\end{array}$ & $\begin{array}{l}\text { Lower risk of disease } \\
\text { transmission and composed } \\
\text { of the most abundant } \\
\text { extracellular matrix protein }\end{array}$ & [48] \\
\hline
\end{tabular}

lungs causes additional stress to any site of injury or disease [63]. These are major morphological and functional characteristics of lung tissue to which adhesive materials must comply in order to offer a safe and efficient intervention. The primary aim of using adhesive materials for biological lung volume reduction is to be able to ameliorate physiological conditions that affect lung function such as hyperventilation, increased airway resistance and decreased elastic recoil [65]. This calls for the development of a lung adhesive material that not only complies with the lung environment, but also overcomes the limitations posed by existing sealants and adhesives.

Polymeric lung volume reduction

In 2001 the idea of obliteration of emphysematous tissue by collapsing it bronchoscopically rather than via surgical resection was first proposed [66]. The aim was to obtain a sustained collapse by delivering a 


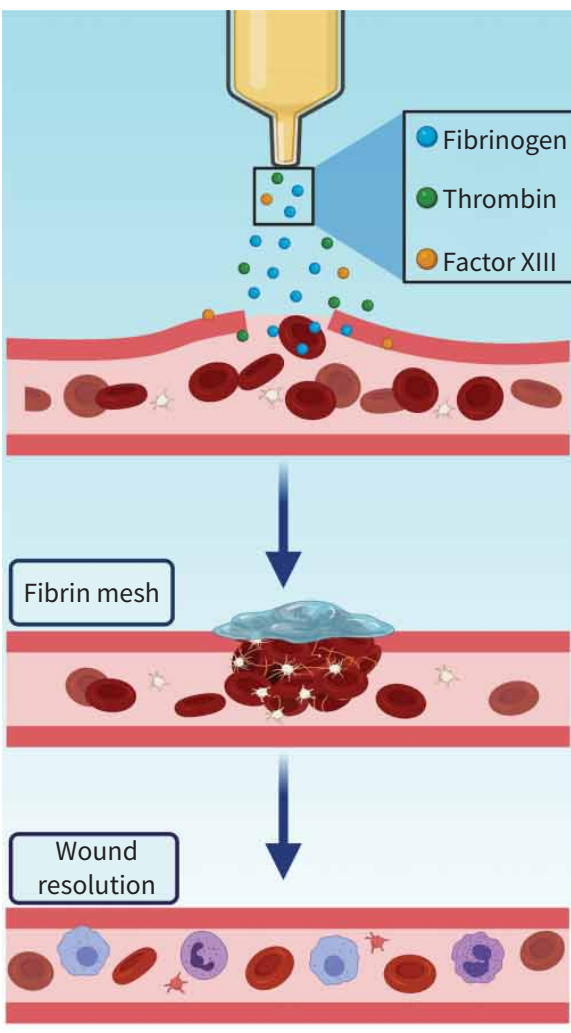

Haemostat

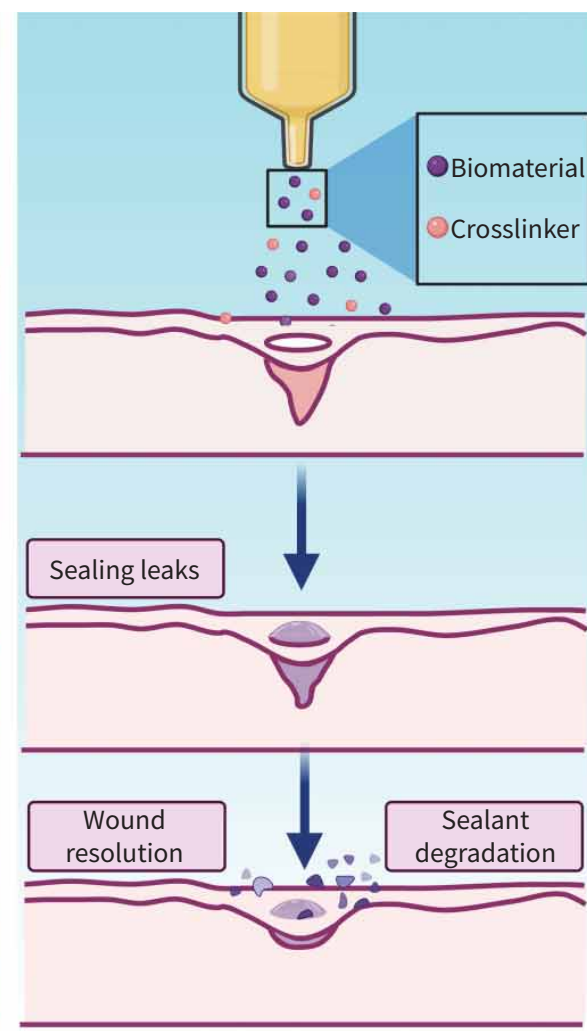

Sealant

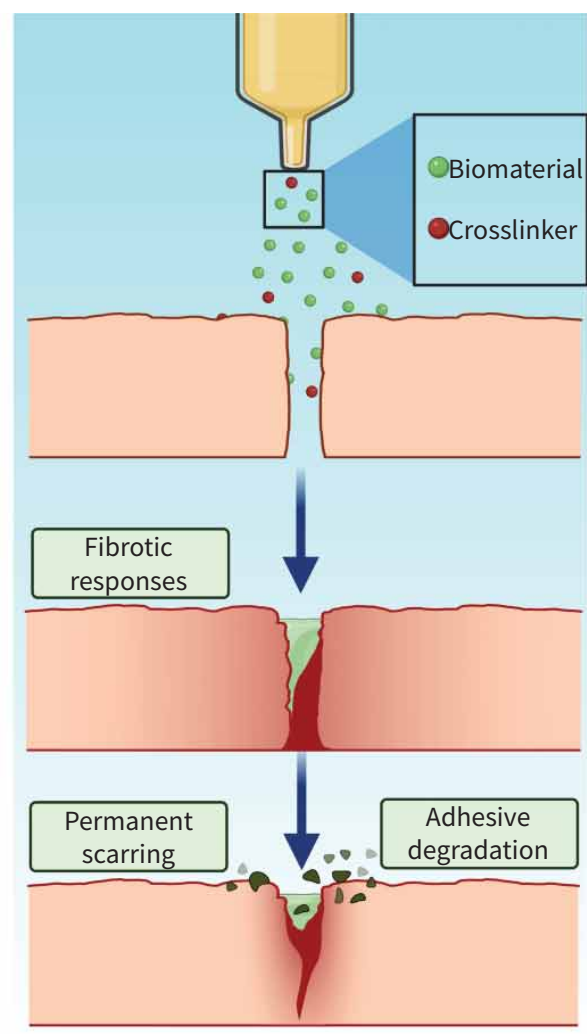

Adhesive

FIGURE 1 Mechanism of action of lung haemostats, sealants and bio-adhesives. Haemostats are biomaterials that control bleeding upon application by forming a localised clot, bolstering the inherent coagulation ability at the bleeding site. Tissue sealants and bio-adhesives react with surface proteins to form covalent material-tissue bonds. Sealants are used to prevent air and/or liquid leakage from a surgical incision, while bio-adhesives crosslink tissue together. These materials degrade gradually as the wound heals.

fibrin-based material to fill, polymerise in situ and seal the targeted region to achieve maximum atelectasis $[55,66]$. The material induces an inflammatory response that initiates the formation of a localised and irreversible scar as well as contraction of the hyperinflated lung, which contributes to the reduction of the overall lung volume [55]. These changes are the result of the remodelling of the pulmonary parenchyma, which has been linked to mononuclear cell infiltration and fibroblast proliferation [55]. The collapsed portion of the lung cannot re-expand as surrounding airways and collateral channels are blocked by the polymerised material. This first-generation lung adhesive was commonly referred to as biological lung volume reduction (Bio-LVR) [55, 67, 68] and was replaced by a polymeric foam called AeriSeal or emphysematous lung sealant (ELS) [27-29, 69, 70]. Since its approval for use in Europe in 2011, several case studies and clinical trials have reported the use of AeriSeal in lung volume reduction [27-30, 69-71]. Essentially, these uncontrolled trials indicated promising efficacy of AeriSeal in reducing lung volume, improving gas trapping, pulmonary function, exercise capacity and quality of life of patients with advanced heterogeneous upper lobe predominant and homogeneous emphysema [27, 28, 30]. Conversely, they have also repeatedly demonstrated severe adverse effects following treatment with ELS including leukocytosis and fever in the majority of patients ( 85\%), COPD exacerbations ( 30\%) and haemoptysis and pneumonia/pneumonitis ( 5-10\%) [27, 28]. A trial conducted by Come et al. [29] further evaluated the safety and efficacy of ELS in a randomised controlled setting. The participants were divided into two groups: ELS plus medical treatment and medical treatment alone (control group). Overall, the ELS treatment was well tolerated and no procedural side-effects were noted. Despite early termination of this study, data available at 3 months suggested a significant improvement in forced expiratory volume in $1 \mathrm{~s}$ $\left(\mathrm{FEV}_{1}\right)$, quality of life and dyspnoea in the ELS-treated group as compared to the control group. Apart from dyspnoea, these improvements persisted over 6 months. However, two deaths were recorded in the treatment group. Additionally, other adverse events such as pneumothorax, post-treatment acute inflammatory response, COPD exacerbations and pneumonia were observed. This study substantiated the 
high efficacy of AeriSeal, but highlighted that this treatment is associated with significant risks, which has limited its wide clinical application [29]. Furthermore, a recent study demonstrated significant volume reduction on computed tomography, but a lack of clinical benefit of administering a much lower dose and staged delivery of AeriSeal in emphysema patients (STAGE, NCT02877459). In contrast, administration of lower volume of AeriSeal was successfully used to reverse collateral ventilation in a patient recommended to undergo volume reduction with EBV [72]. Currently, two more studies are recruiting patients for evaluating the feasibility, safety and efficacy of injecting AeriSeal to block interlobar collateral ventilation for enhanced EBV treatment (Mind The Gap - Crossing Borders Study, NCT04256408; and CONVERT, NCT04559464).

One of the components used to produce AeriSeal, glutaraldehyde, is the most commonly used crosslinking agent in biomedical applications and well known for its cytotoxicity. This could be a major contributor to the adverse events observed upon administration of this adhesive. Unreacted glutaraldehyde is typically washed away in in vitro studies after polymerisation; however, this is challenged in a clinical setting and thus potentially harmful for patients. Moreover, the degraded by-products (cyanoacetate and formaldehyde) of glutaraldehyde could remain a continuous source of cytotoxicity. Extensive in vitro and animal studies are required to decipher the underlying reactions that occur upon delivery of the adhesive that have led to exacerbations, infections and even death. Alternatively, biocompatible crosslinking agents such as carboxylic acids and genipin are being examined for biomedical application in wet environment [73, 74].

\section{Autologous blood}

The bio-adhesive properties of blood were utilised in BLVR for the first time in 2008 to treat emphysematous bullae [40]. Autologous blood was delivered using an intrabronchial catheter followed by fibrinogen and thrombin solution into the bullae, which shrunk dramatically (from $12 \mathrm{~cm}$ to $3 \mathrm{~cm}$ in diameter) providing functional and symptomatic relief to the patient, who remained in remission for $\geqslant 12$ months post-treatment. This treatment worked on the principle that the formation of a blood clot contributed to plugging, generation of scar tissue and collapse of emphysematous alveoli [40]. In a study by BAKEER et al. [41], patients were either treated with autologous blood mixed with cyklokapron and calcium chloride $(n=7)$ or with locally prepared fibrin glue $(n=8)$ which was delivered to targeted segments of emphysematous tissue. Cyklokapron reduces excessive blood loss, while calcium hastens clotting. The pulmonary function and quality of life improved in patients treated with blood and fibrin glue at 12 weeks as compared to the baseline. However, no significant difference was observed between the different treatment groups. Moreover, one patient treated with blood developed pneumonia post-operatively [41]. In another study performed to relieve unmanageable dyspnoea, autologous blood followed by a thrombin solution was delivered to the most impaired lobe periodically until an inflammatory response (pneumonia) was achieved [42]. However, this was also accompanied by fever, hypoxaemia and tachycardia, which were relieved by steroids. The eosinophilia lasted for weeks after the initial induction of pneumonia. Upon recovery from these inflammatory responses $\mathrm{FEV}_{1}$ and the inspiratory capacity were improved, but only temporarily, and returned to baseline levels within 6-12 months [42]. Lung volume reduction and dyspnoea improvement has also been achieved using three-dimensional navigated bronchoscopy for targeted instillation of autologous blood in bullous emphysema [43]. Additionally, the conversion of collateral ventilation-positive to collateral ventilation-negative lobes has been attempted with the help of autologous blood or blood derivatives; however, due to lack of sufficient efficacy this study was stopped (Mind The Gap, NTR5007). Although the approach of utilising autologous blood is cost-effective, it is also prone to induce infection and adverse events caused by inflammation. Moreover, theoretically, blood and its by-products will be broken down and absorbed by the body gradually, offering only a temporary effect.

It is noteworthy that all of these methods are heavily dependent on the induction of inflammatory responses that result in remodelling of the lung parenchyma and formation of fibrotic tissue. These responses are stimulated by the presence of natural or synthetic materials which gradually degrade and are resorbed. This raises the major concern of diminishing atelectasis over time. Hence, there is certainly scope for approaches with alternative mechanisms of action to reduce the risk of associated adverse events and hospitalisation days, while still offering improved quality of life through symptomatic and functional relief.

Future perspectives

Current BLVR approaches are either beneficial only to a small group of patients or induce severe inflammatory responses and adverse events. The development of a BLVR strategy that is applicable to and well tolerated by all emphysematous patients, irrespective of their phenotypes, will help combat the growing prevalence of COPD. Hence, there remains an unmet need for the development of a bio-adhesive material for volume reduction that can be delivered using a catheter and has strong wet adhesive properties 
that enable fusing of disintegrated lung tissue. The viscosity of the material should be tuned such that upon delivery to the airway subsegments, it should disperse within the defect site, but rapidly polymerise to minimise leakage to nontargeted regions (figure 2). Ideally, the polymerisation reaction must not generate excessive heat, nor should the swollen polymerised material compress surrounding tissue/organs. For a single application and permanent lung volume reduction, the material should remain unaltered and should not degrade over an extended period of time. Additionally, adequate biomechanical properties of the material such as high tissue-bonding strength (tensile and lap shear strength), elasticity, toughness and stiffness are crucial to enable the material to withstand the constant movements of the respiratory muscles. They should facilitate restoration of the physiological properties of the diseased lung tissue, such as restoring diminished overall stiffness and elastic recoil in emphysematous lungs. However, currently the accurate biomechanical characteristics of a bio-adhesive to prime it for clinical studies remain unknown and extensive fundamental research is needed to establish these criteria. Furthermore, movement of the lungs, presence of bodily fluids, and mechanical forces at the application site can irreversibly damage the

a)

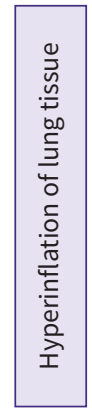

b)

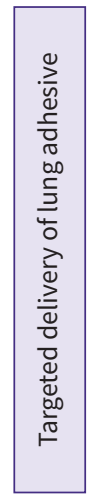

c)

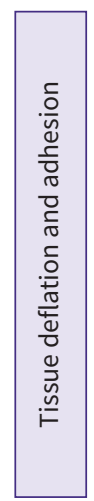

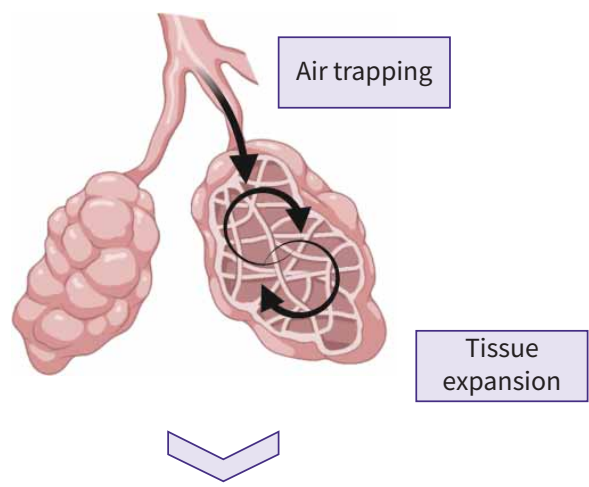

$\checkmark$

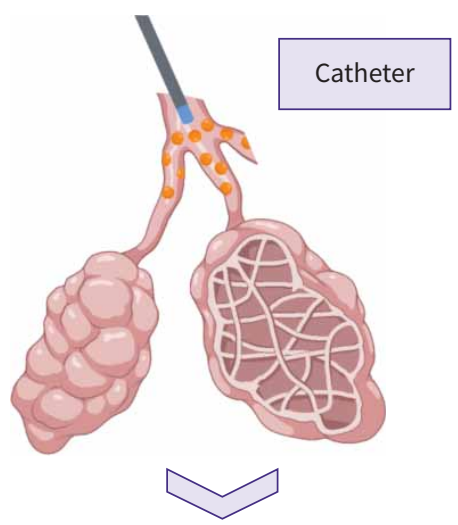

FIGURE 2 Illustration of the mechanism of action of prospective/future lung bio-adhesive for bronchoscopic lung volume reduction. a) Damaged alveoli with air trapping and hyperinflation in an emphysematous lung; b) bronchoscopic delivery of prospective lung bio-adhesive to airway subsegments; c) rapid in situ polymerisation of the bio-adhesive material that crosslinks together the surrounding destroyed/damaged tissue, contracting it, removing trapped air, maximising atelectasis and reducing overall lung volume. 


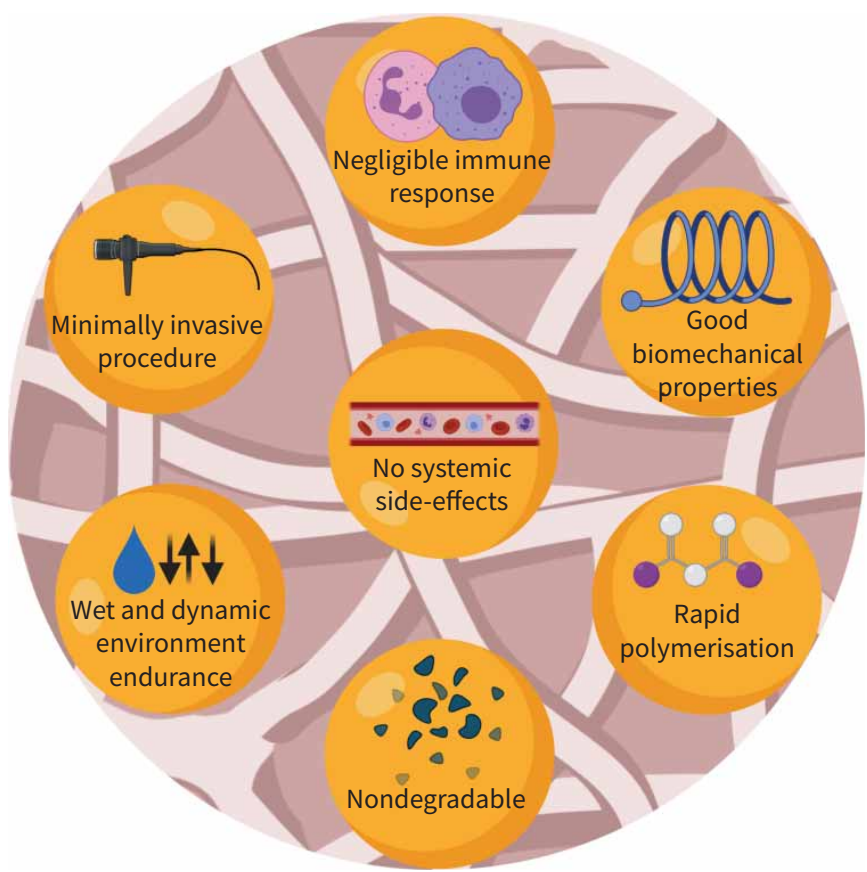

FIGURE 3 Summary of characteristics of an ideal lung adhesive for bronchoscopic lung volume reduction. To develop a one-step permanent bronchoscopic lung volume reduction strategy using lung bio-adhesives, characteristics such as good biomechanical properties, rapid in situ polymerisation, nonbiodegradability, zero systemic side-effects, negligible immune reactions, bronchoscopic delivery and ability to adapt to wet and dynamic environment are desirable.

bio-adhesive. Self-healing capacity of the material would ensure self-repair and restoration of native function and properties without external intervention. With the recent advances in bio-orthogonal approaches, the material can be made tunable on demand to accommodate for desirable cellular responses. Ideally, the intervention should invoke minimal inflammatory responses to enable fusing and tissue contraction, but should not lead to foreign body reactions or adverse events upon administration or in the long term. Adverse events such as pneumonia, pneumothorax, COPD exacerbation or respiratory infections in vulnerable patients such as those affected by severe emphysema can prolong hospitalisation, reduce quality of life and are sometimes fatal, and should thus be avoided. The outcomes of the treatment must be restricted to the lungs without systemic side-effects. Importantly, the outcomes of the treatment including enhanced lung function and exercise capacity should be sustainable long-term. The ideal novel material, in comparison to LVRS, should lower the rate of morbidity and mortality and improve clinical outcomes such as $\mathrm{FEV}_{1} /$ forced vital capacity ratio, residual volume, total lung volume, exercise capacity and dyspnoea score. These characteristics are summarised in figure 3. To this end, several novel materials with superior adhesion and mechanical properties are being developed. For instance, methacryloyl-substituted tropoelastin and gelatin methacryloyl based adhesives effectively sealed large air leaks in animal models in the absence of sutures and staples [64, 75]. However, these novel biomaterials are yet to be tested in a BLVR setting. Excitingly, advances in chemical engineering have enabled progress of smart materials with remarkable properties including self-sealing, self-healing, self-adherence, high stretchability, high toughness and reversibility [76-81] that have potentially paved the way for the establishment of an ideal lung bio-adhesive for volume reduction.

\section{Conclusion}

Emphysema hugely affects even simple daily activities of COPD patients. Initially, LVRS was recommended as a treatment option for COPD patients, but the very strict selection criteria and associated rate of morbidity with this intervention discouraged its widespread application. Alternatively, different BLVR methods were gradually developed including implantation of one-way valves, stents, coils and thermal vapour ablation. Although one-way valves are the most successful of all the BLVR approaches, only a small subpopulation of patients benefit from this treatment. BLVR using bio-adhesives is a novel field of research that is rapidly gaining traction. Several haemostats and sealants have been employed for 
lung repair and regeneration or to prevent air and body fluid leaks, but have not been explored for permanent volume reduction, probably due to their unfavourable properties. To the best of our knowledge, only AeriSeal has been extensively investigated and used therapeutically for volume reduction. A major drawback of AeriSeal is its induction of inflammatory responses and adverse events upon administration. Nevertheless, ongoing efforts combining two BLVR methods such as AeriSeal and EBV are promising. Moreover, with improved diagnostic tools comes better stratification of patients, which will help clinicians to more accurately identify and execute effective treatments and care. Finally, for a safe and one-time solution using lung bio-adhesive, a biocompatible and nondegradable material is desirable. Although a safe and effective adhesive has yet to be developed, promising formulations have become within range of becoming an achievable reality given the advances in innovative techniques in chemistry and bioengineering.

Provenance: Submitted article, peer reviewed.

Acknowledgements: The figures were partially created using BioRender (BioRender.com).

Conflict of interest: M.M. Joglekar has nothing to disclose. D-J. Slebos reports non-financial support and other from PulmonX Corp., CA, USA (physician advisor and investigator), outside the submitted work. J. Leijten has nothing to disclose. J.K. Burgess has nothing to disclose. S.D. Pouwels has nothing to disclose.

Support statement: M.M. Joglekar is funded by the Graduate School of Medical Sciences of the University of Groningen (no grant number). J. Leijten acknowledges financial support from an Innovative Research Incentives Scheme Vidi award (\#17522) from the Netherlands Organization for Scientific Research (NWO) and from the European Research Council (ERC, Starting Grant, \#759425). J.K. Burgess also acknowledges support from the NWO (Aspasia 015.013.010). Funding information for this article has been deposited with the Crossref Funder Registry.

\section{References}

1 Soriano JB, Kendrick PJ, Paulson KR, et al. Prevalence and attributable health burden of chronic respiratory diseases, 1990-2017: a systematic analysis for the Global Burden of Disease Study 2017. Lancet Respir Med 2020; 8: 585-596.

2 Global Initiative for Chronic Obstructive Lung Disease. Global Strategy for the Diagnosis, Management, and Prevention of Chronic Obstructive Pulmonary Disease (2021 Report). Available from: https://goldcopd.org/ Date last updated: 25 November 2020. Date last accessed: 30 April 2021.

3 Agustí A, Hogg JC. Update on the pathogenesis of chronic obstructive pulmonary disease. N Engl J Med 2019; 381: $1248-1256$

4 Shah PL, Slebos D-J. Bronchoscopic interventions for severe emphysema: where are we now? Respirology 2020; 25: 972-980.

5 Fishman A, Martinez F, Naunheim K, et al. A randomized trial comparing lung-volume-reduction surgery with medical therapy for severe emphysema. N Engl J Med 2003; 348: 2059-2073.

6 Shah PL, Herth FJ, van Geffen WH, et al. Lung volume reduction for emphysema. Lancet Respir Med 2017; 5: 147-156.

7 Klooster K, Hartman JE, Ten Hacken NHT, et al. One-year follow-up after endobronchial valve treatment in patients with emphysema without collateral ventilation treated in the STELVIO trial. Respiration 2017; 93: $112-121$.

8 Valipour A, Slebos D-J, Herth F, et al. Endobronchial valve therapy in patients with homogeneous emphysema. Results from the IMPACT study. Am J Respir Crit Care Med 2016; 194: 1073-1082.

9 Criner GJ, Sue R, Wright S, et al. A multicenter randomized controlled trial of zephyr endobronchial valve treatment in heterogeneous emphysema (LIBERATE). Am J Respir Crit Care Med 2018; 198: 1151-1164.

10 Kemp SV, Slebos D-J, Kirk A, et al. A multicenter randomized controlled trial of zephyr endobronchial valve treatment in heterogeneous emphysema (TRANSFORM). Am J Respir Crit Care Med 2017; 196: 1535-1543.

11 Gillespie CT, Sterman DH, Cerfolio RJ, et al. Endobronchial valve treatment for prolonged air leaks of the lung: a case series. Ann Thorac Surg 2011; 91: 270-273.

12 Koster TD, Klooster K, Ten Hacken NHT, et al. Endobronchial valve therapy for severe emphysema: an overview of valve-related complications and its management. Expert Rev Respir Med 2020; 14: 1235-1247.

13 Klooster K, Slebos D-J. Endobronchial valves for the treatment of advanced emphysema. Chest 2021; 159: 1833-1842.

14 Springmeyer SC, Bolliger CT, Waddell TK, et al. Treatment of heterogeneous emphysema using the spiration IBV valves. Thorac Surg Clin 2009; 19: 247-253.

15 Shah PL, Slebos D-J, Cardoso PFG, et al. Bronchoscopic lung-volume reduction with Exhale airway stents for emphysema (EASE trial): randomised, sham-controlled, multicentre trial. Lancet 2011; 378: 997-1005. 
16 Shah PL, Slebos D-J, Cardoso PFG, et al. Design of the exhale airway stents for emphysema (EASE) trial: an endoscopic procedure for reducing hyperinflation. BMC Pulm Med 2011; 11: 1.

17 Sciurba FC, Criner GJ, Strange C, et al. Effect of endobronchial coils vs usual care on exercise tolerance in patients with severe emphysema: the RENEW randomized clinical trial. JAMA 2016; 315: 2178-2189.

18 Slebos D-J, Klooster K, Ernst A, et al. Bronchoscopic lung volume reduction coil treatment of patients with severe heterogeneous emphysema. Chest 2012; 142: 574-582.

19 Herth FJF, Eberhard R, Gompelmann D, et al. Bronchoscopic lung volume reduction with a dedicated coil: a clinical pilot study. Ther Adv Respir Dis 2010; 4: 225-231.

20 Dutau H, Bourru D, Guinde J, et al. Successful late removal of endobronchial coils. Chest 2016; 150: e143-e145.

21 Shah PL, Zoumot Z, Singh S, et al. Endobronchial coils for the treatment of severe emphysema with hyperinflation (RESET): a randomised controlled trial. Lancet Respir Med 2013; 1: 233-240.

22 Evaluation of the Free Flow Medical Lung Tensioning Device System for the Treatment of Severe Emphysema (EFFORT). 2020. https://clinicaltrials.gov/ct2/show/NCT04520152

23 Shah PL, Gompelmann D, Valipour A, et al. Thermal vapour ablation to reduce segmental volume in patients with severe emphysema: STEP-UP 12 month results. Lancet Respir Med 2016; 4: e44-e45.

24 Gompelmann D, Eberhardt R, Ernst A, et al. The localized inflammatory response to bronchoscopic thermal vapor ablation. Respiration 2013; 86: 324-331.

25 Gompelmann D, Heussel CP, Eberhardt R, et al. Efficacy of bronchoscopic thermal vapor ablation and lobar fissure completeness in patients with heterogeneous emphysema. Respiration 2012; 83: 400-406.

26 Snell GI, Hopkins P, Westall G, et al. A feasibility and safety study of bronchoscopic thermal vapor ablation: a novel emphysema therapy. Ann Thorac Surg 2009; 88: 1993-1998.

27 Herth FJF, Gompelmann D, Stanzel F, et al. Treatment of advanced emphysema with emphysematous lung sealant (AeriSeal). Respiration 2011; 82: 36-45.

28 Kramer MR, Refaely Y, Maimon N, et al. Bilateral endoscopic sealant lung volume reduction therapy for advanced emphysema. Chest 2012; 142: 1111-1117.

29 Come CE, Kramer MR, Dransfield MT, et al. A randomised trial of lung sealant versus medical therapy for advanced emphysema. Eur Respir J 2015; 46: 651-662.

30 Magnussen $\mathrm{H}$, Kramer MR, Kirsten A-M, et al. Effect of fissure integrity on lung volume reduction using a polymer sealant in advanced emphysema. Thorax 2012; 67: 302-308.

31 Herth FJF, Eberhardt R, Ingenito EP, et al. Assessment of a novel lung sealant for performing endoscopic volume reduction therapy in patients with advanced emphysema. Expert Rev Med Devices 2011; 8: 307-312.

32 Herth FJF, Slebos D-J, Criner GJ, et al. Endoscopic lung volume reduction: an expert panel recommendation update 2019. Respiration 2019; 97: 548-557.

33 Welling JBA, Hartman JE, Augustijn SWS, et al. Patient selection for bronchoscopic lung volume reduction. Int J Chron Obstruct Pulmon Dis 2020; 15: 871-881.

34 Slebos D-J, Hartman JE, Klooster K, et al. Bronchoscopic coil treatment for patients with severe emphysema: a meta-analysis. Respiration 2015; 90: 136-145.

35 Garner JL, Kemp SV, Srikanthan K, et al. 5-year survival after endobronchial coil implantation: secondary analysis of the first randomised controlled trial, RESET. Respiration 2020; 99: 154-162.

36 Mineshita M, Slebos D-J. Bronchoscopic interventions for chronic obstructive pulmonary disease. Respirology 2014; 19: 1126-1137.

37 Pedersen TB, Honge JL, Pilegaard HK, et al. Comparative study of lung sealants in a porcine ex vivo model. Ann Thorac Surg 2012; 94: 234-240.

38 Annabi N, Yue K, Tamayol A, et al. Elastic sealants for surgical applications. Eur J Pharm Biopharm 2015; 95 27-39.

39 McGuire AL, Yee J. Clinical outcomes of polymeric sealant use in pulmonary resection: a systematic review and meta-analysis of randomized controlled trials. J Thorac Dis 2018; 10: Suppl. 32, S3728-S3739.

40 Kanoh S, Kobayashi H, Motoyoshi K. Intrabullous blood injection for lung volume reduction. Thorax 2008; 63 : 564-565.

41 Bakeer M, Abdelgawad TT, El-Metwaly R, et al. Low cost biological lung volume reduction therapy for advanced emphysema. Int J Chron Obstruct Pulmon Dis 2016; 11: 1793-1800.

42 Mizumori $\mathrm{Y}$, Mochiduki $\mathrm{Y}$, Nakahara $\mathrm{Y}$, et al. Effects of bronchoscopic lung volume reduction using transbronchial infusion of autologous blood and thrombin in patients with severe chronic obstructive pulmonary disease. $J$ Thorac Dis 2015; 7: 413-421.

43 Hetzel J, Boeckeler M, Lewis RA, et al. Use of 3-D navigation to target the site of autologous blood installation for lung volume reduction in bullous emphysema. Chron Respir Dis 2020; 17: 1479973120903556.

44 Belcher E, Dusmet M, Jordan S, et al. A prospective, randomized trial comparing BioGlue and Vivostat for the control of alveolar air leak. J Thorac Cardiovasc Surg 2010; 140: 32-38.

45 Bao Z, Gao M, Sun Y, et al. The recent progress of tissue adhesives in design strategies, adhesive mechanism and applications. Mater Sci Eng C Mater Biol Appl 2020; 111: 110796. 
46 Leggat PA, Smith DR, Kedjarune U. Surgical applications of cyanoacrylate adhesives: a review of toxicity. ANZ J Surg 2007; 77: 209-213.

47 Bhagat V, Becker ML. Degradable adhesives for surgery and tissue engineering. Biomacromolecules 2017; 18 : 3009-3039.

48 Rathinam S, Naidu BV, Nanjaiah P, et al. BioGlue and Peri-strips in lung volume reduction surgery: pilot randomised controlled trial. J Cardiothorac Surg 2009; 4: 37.

49 Tsilimigras DI, Antonopoulou A, Ntanasis-Stathopoulos I, et al. The role of BioGlue in thoracic surgery: a systematic review. J Thorac Dis 2017; 9: 568-576.

50 Fürst W, Banerjee A. Release of glutaraldehyde from an albumin-glutaraldehyde tissue adhesive causes significant in vitro and in vivo toxicity. Ann Thorac Surg 2005; 79: 1522-1528.

51 Fuller C. Reduction of intraoperative air leaks with Progel in pulmonary resection: a comprehensive review. J Cardiothorac Surg 2013; 8: 90.

52 Nam S, Mooney D. Polymeric tissue adhesives. Chem Rev 2021; 121: 11336-11384.

53 Annabi N, Tamayol A, Shin SR, et al. Surgical materials: current challenges and nano-enabled solutions. Nano Today 2014; 9: 574-589.

54 Ge L, Chen S. Recent advances in tissue adhesives for clinical medicine. Polymers 2020; 12: 939.

55 Reilly J, Washko G, Pinto-Plata V, et al. Biological lung volume reduction: a new bronchoscopic therapy for advanced emphysema. Chest 2007; 131: 1108-1113.

56 Brannigan RP, Khutoryanskiy VV. Progress and current trends in the synthesis of novel polymers with enhanced mucoadhesive properties. Macromol Biosci 2019; 19: 1900194.

$57 \mathrm{Kim} \mathrm{K}, \mathrm{Kim} \mathrm{K}$, Ryu JH, et al. Chitosan-catechol: a polymer with long-lasting mucoadhesive properties. Biomaterials 2015; 52: 161-170.

$58 \mathrm{Xu} \mathrm{J}$, Soliman GM, Barralet J, et al. Mollusk glue inspired mucoadhesives for biomedical applications. Langmuir 2012; 28: 14010-14017.

59 Bré LP, Zheng Y, Pêgo AP, et al. Taking tissue adhesives to the future: from traditional synthetic to new biomimetic approaches. Biomater Sci 2013; 1: 239-253.

60 Brubaker CE, Kissler H, Wang L-J, et al. Biological performance of mussel-inspired adhesive in extrahepatic islet transplantation. Biomaterials 2010; 31: 420-427.

61 Perrini M, Barrett D, Ochsenbein-Koelble N, et al. A comparative investigation of mussel-mimetic sealants for fetal membrane repair. J Mech Behav Biomed Mater 2016; 58: 57-64.

62 Mehdizadeh M, Weng H, Gyawali D, et al. Injectable citrate-based mussel-inspired tissue bioadhesives with high wet strength for sutureless wound closure. Biomaterials 2012; 33: 7972-7983.

63 Milenkovic B, Janjic SD, Popevic S. Review of lung sealant technologies for lung volume reduction in pulmonary disease. Med Devices 2018; 11: 225-231.

64 Assmann A, Vegh A, Ghasemi-Rad M, et al. A highly adhesive and naturally derived sealant. Biomaterials 2017; 140: 115-127.

65 Lee HJ, Shojaee S, Sterman DH. Endoscopic lung volume reduction. An American perspective. Ann Am Thorac Soc 2013; 10: 667-679.

66 Ingenito EP, Reilly JJ, Mentzer SJ, et al. Bronchoscopic volume reduction: a safe and effective alternative to surgical therapy for emphysema. Am J Respir Crit Care Med 2001; 164: 295-301.

67 Criner GJ, Pinto-Plata V, Strange C, et al. Biologic lung volume reduction in advanced upper lobe emphysema: phase 2 results. Am J Respir Crit Care Med 2009; 179: 791-798.

68 Refaely Y, Dransfield M, Kramer MR, et al. Biologic lung volume reduction therapy for advanced homogeneous emphysema. Eur Respir J 2010; 36: 20-27.

69 Falkenstern-Ge RF, Ingerl H, Kohlhaeufl M. Treatment of severe advanced emphysema with volume reduction using lung sealant: a case report of 2 patients. J Bronchology Interv Pulmonol 2013; 20: 58-62.

70 Falkenstern-Ge RF, Ingerl H, Kohlhäufl M. Severe emphysema treated by endoscopic bronchial volume reduction with lung sealant (AeriSeal). Case Rep Pulmonol 2013; 2013: 361391.

71 Falkenstern-Ge RF, Ingerl H, Kohlhäufl M. Lung emphysema treated successfully using volume reduction with lung sealant (AeriSeal ${ }^{\oplus}$ ). Open Med 2013; 8: 648-651.

72 Ing A, Sullivan C, Hersch N, et al. Reversal of collateral ventilation using endobronchial polymer sealant in a patient with emphysema undergoing endoscopic lung volume reduction (ELVR) with valves: a case report and proof of concept. J Bronchology Interv Pulmonol 2020; 27: e14-e16.

73 Reddy N, Reddy R, Jiang Q. Crosslinking biopolymers for biomedical applications. Trends Biotechnol 2015; 33 : 362-369.

74 Fan C, Fu J, Zhu W, et al. A mussel-inspired double-crosslinked tissue adhesive intended for internal medical use. Acta Biomater 2016; 33: 51-63.

75 Annabi N, Zhang Y-N, Assmann A, et al. Engineering a highly elastic human protein-based sealant for surgical applications. Sci Transl Med 2017; 9: eaai7466.

76 Guo J, Kim GB, Shan D, et al. Click chemistry improved wet adhesion strength of mussel-inspired citrate-based antimicrobial bioadhesives. Biomaterials 2017; 112: 275-286. 
77 Shin M, Park S-G, Oh B-C, et al. Complete prevention of blood loss with self-sealing haemostatic needles. Nat Mater 2017; 16: 147-152.

78 Blacklow SO, Li J, Freedman BR, et al. Bioinspired mechanically active adhesive dressings to accelerate wound closure. Sci Adv 2019; 5: eaaw3963.

79 Li J, Celiz AD, Yang J, et al. Tough adhesives for diverse wet surfaces. Science 2017; 357: 378-381.

80 Pei $\mathrm{X}$, Zhang $\mathrm{H}$, Zhou $\mathrm{Y}$, et al. Stretchable, self-healing and tissue-adhesive zwitterionic hydrogels as strain sensors for wireless monitoring of organ motions. Mater Horiz 2020; 7: 1872-1882.

81 Li P, She W, Luo Y, et al. One-pot, self-catalyzed synthesis of self-adherent hydrogels for photo-thermal, antimicrobial wound treatment. J Mater Chem B 2021; 9: 159-169. 